\title{
Kitekintés
}

GIMES JÚLIA GONDOZÁSÁBAN

\section{ÉHEZTETETT MELANÓMA}

Az melanóma sejtjeinek egyfajta éheztetésére alkalmas gyógyszert fejlesztenek amerikai kutatók (Sanford Burnham Prebys Medical Discovery Institute). Az IMD-0354 nevű gyógyszerjelölt molekula sejtkultúrákban és festékes bőrdaganatban szenvedő egerekben egyaránt gátolta a tumorsejtek szaporodását.

A daganatoknak a korlátlan osztódáshoz sok energiára van szükségük, és vannak olyanok, köztük a melanóma is, amelyek energiaellátásukat a glutamin nevü aminosav nagy mennyiségü felvételével segítik.

Ze'eV Ronai és munkatársai olyan vegyületeket kerestek, amelyek gátolják a glutamint a sejtekbe juttató ún. SLC1A5 transzporter fehérje működését.

Vegyész kollégáik segítségével több mint 7000 vegyületet teszteltek le, és köztük 20 ígéretesnek tünő anyagot találtak. Ezek közül választották ki az IMD-0354 jelzésüt, amely hatékonyan megakadályozza, hogy a szállítófehérje egyáltalán elérje a sejtmembránt. Ez eleve kizárja azt a lehetőséget, hogy azon bármit átjuttasson. Mivel a melanómán kívül sokféle tumor „glutaminfüggő”, megvan az esély arra, hogy a vegyület másféle ráksejtek ellen is bevethető legyen.

A kutatók most azon dolgoznak, hogy az IMD-0354 kémiai módosításával javítsák azokat a fizikokémiai sajátságait, amelyek növelik a gyakorlati felhasználás esélyét, és felgyorsíthatják a preklinikai vizsgálatokat.

A melanóma kezelésében az elmúlt időszakban nagy elörelépések történtek, például az immunterápiával, melynek elméleti megalapozását 2019-ben orvosi Nobel-díjjal jutalmazták. Mivel azonban a betegek egy részénél ez hatástalan, más kezelések esetén pedig számítani kell a daganatsejtek rezisztenciájának kialakulására, valóban nagy szükség lenne egy újabb gyógyítási lehetőségre.

Feng, Y. - Pathria, G. - Heynen-Genel, S. et al.: Identification and Characterization of IMD-0354 as a Glutamine Carrier Protein Inhibitor in Melanoma. Molecular Cancer Therapeutics, published on February 25, 2021. DOI: 10.1158/1535-7163.MCT-20-0354 


\section{EMBRIÓK? VAGY NEM?}

Emberi őssejtekből hólyagcsíraszerü képződményt hozott létre két egymástól független kutatócsoport is - írja a Nature. A hólyagcsíra vagy blasztociszta az emberi egyedfejlődés során a megtermékenyítéstől számított 4. napon alakul ki és a 7-8. napon ágyazódik be a méh falába. A humán embriókon való kísérletezés etikai problémái miatt ezt a legkorábbi fejlődési szakaszt is rendkívül nehéz vizsgálni, ezért jelentősek az őssejtekkel most elért eredmények.

Az amerikai University of Texas és a kínai Kunming Medical University kutatói emberi őssejteket különböző növekedési faktorok sorozatával kezeltek, és így hozták létre az általuk blasztoidoknak nevezett mesterséges blasztocisztákat. A blasztoidok morfológiájuk, méretük, az őket alkotó sejtek száma, összetétele és a különböző sejtek elhelyezkedése alapján az ,igazi” hólyagcsírához igen hasonlónak bizonyultak. A blasztoidokat embrionális őssejtekből és testi sejtek visszaprogramozásával előállított indukált pluripotens őssejtekből egyaránt létre tudták hozni.

A kanadai Monash Universityn működő másik munkacsoport felnőtt bőrsejtek visszaprogramozásával állított elő blasztoid stuktúrákat.

Mindkét kutatás során hasonló eredményességgel jutottak a kívánatos blasztoidokhoz: az elvárásoknak megfelelően csak a sejtek 10 százaléka alakult át. Ugyanakkor mindegyik rendszer tartalmazott „oda nem illő” sejttípusokat is.

A blasztoidok tanulmányozásának célja az igen korai fejlődési szakasz génjeinek, mutációinak strukturális vizsgálata, a fejlődési rendellenességek kialakulásának jobb megértése. Az azonban kérdéses, hogy a blasztoidok valójában mennyire feleltethetők meg a blasztocisztáknak, azaz a vizsgálatuk során levont következtetések az „igazi” struktúrákra mennyire extrapolálhatók.

A hasonlóság ugyanakkor etikai kérdéseket is felvet; nem véletlen, hogy e mesterséges képződményeket csak két hétig hagyták fejlődni, tehát mindkét csoport kutatói rájuk is érvényesnek tekintették az emberi embriók laboratóriumi vizsgálatára sok országban előírt szabályokat.

A terület gyors fejlődése miatt a Nemzetközi Össejt Kutatási Társaság (ISSCR) májusban nyilvánosságra kerülő módosított etikai irányelvei tartalmazzák majd az embriószerủ struktúrák kutatása során követendő szabályokat is.

Liu, X. - Tan, J. P. - Schröder, J. et al.: Modelling human blastocysts by reprogramming fibroblasts into iBlastoids. Nature, 17. March 2021. DOI: 10.1038/s41586-021-03372-y

Yu, L. -Wei, Y.- Duan, J. et al.: Blastocyst-like structures generated from human pluripotent stem cells. Nature, 17. March 2021. DOI: 10.1038/s41586-021-03356-y 


\section{LÁM AZ ENYÉM, LÁM AZ ENYÉM SÖTÉTKÉK...}

A szem színének genetikája jóval bonyolultabb, mint eddig hitték. Korábban azt gondolták, hogy a szemszínt mindössze 1-2 gén határozza meg, és a barna szín a kékhez képest domináns.

Egy nagy nemzetközi kutatócsoport 195 ezer európai és ázsiai ember örökítőanyagának analízisével 50 olyan, eddig ismeretlen gént talált, amelyek szerepet játszanak a szem színének kialakításában. Bizonyos génekről kiderítették, hogy részt vesznek a melanin pigmentáció szabályozásában, míg mások a szivárványhártya felépítésének és struktúrájának kialakításában. A kutatók azt remélik, hogy felfedezésük közelebb vihet bizonyos, a szem festékanyagaival kapcsolatos betegségek, például pigmentglaukóma, szemalbinizmus kialakulásának megértéshez, majd gyógyításához.

A tanulmány érdekes következtetése, hogy az ázsiai emberek különböző árnyalatú barna szemszínéhez tartozó genetikai mintázatok leginkább az európaiak sötétbarnától a világoskékig terjedő színskálájának mintázataihoz hasonlítanak.

Simcoe, M. - Valdes, A. - Liu, F. et al.: Genome-wide association study in almost 195,000 individuals identifies 50 previously unidentified genetic loci for eye color. Science Advances, 2021; 7 (11): eabd1239, DOI: 10.1126/sciadv.abd1239

\section{GRÄTZEL-ELEMEK ÉS MICHAEL GRÄTZEL}

Napjainkban a világ elektromosenergia-szükségletének körülbelül 3 százalékát napelemekkel állítják elő. Németországban ez az arány jóval magasabb, 2019-ben 8,2 százalék volt (Ez 47.5 TWh-t jelent. Összehasonlításul: Magyarország villamosenergia-felhasználása ugyanebben az évben $45,4 \mathrm{TWh}$ volt.)

Pontosan harminc évvel ezelött, 1991-ben jelent meg Brian O’Regan és Michael Grätzel cikke, mely a napenergia hasznosításának területén új fejezetet nyitott. A festékmolekulákkal érzékenyített napelem (angol nevének rövidítése alapján DSSC, de ma már Grätzel-elemnek is hívják) megalkotásáért Grätzel 2010-ben elnyerte az egyik legjelentősebb technológiai elismerésnek számító Millennium díjat. Most a DSSC-k továbbfejlesztésében elért legújabb eredményeiről számol be a Michael Grätzel vezette kutatócsoport.

A részletesen ismertetett új, egyszerüen előállitható, és olcsó festékkel 1,24 V kapocsfeszültséget, és ugyanezt egy már kereskedelmi forgalomban kapható festékkel kombinálva, 13,5 százalékos hatásfokot értek el a napenergia elektromos energiává történő átalakításában. Napsütésben a napelemek ezen típusainak hatásfoka nem versenyképes a szilíciumalapú napelemekével, nagy erősségük akkor jön elö, mikor beborul. Képesek szórt fényben, akár beltéren is működni, sőt 
ilyen körülmények között jobb a hatásfokuk. A most leírt kísérleti modell így 34,5 százalékot teljesített.

A Grätzel-elemeket szerte a világon gyártják és használják. Michael Grätzelnek több mint ötven szabadalma van, és egyúttal a legtöbbet hivatkozott kutatók között szerepel. A Magyar Tudomány oldalain is ismertetett csúcskutatók 100 ezres listáján stabilan az abszolút első helyen áll, megelőzve minden élő és számos már nem élő Nobel-díjast. Tényleg lenyügözőek ezek a tudománymetriai mutatók, de nem tudható, hogy az ezen mutatók szerinti rangsor megegyezne-e a tudományos kutatók egyéni teljesítményének rangsorával, ha egyáltalán lehetséges az utóbbit definiálni. (Amit egyébként maguk a százezres lista készítői sem állítanak.)

Haller József: Kutatói rangsorok - A világ és Magyarország. Magyar Tudomány, 181 (2020) 11, 1541-1556. DOI: 10.1556/2065.181.2020.11.11

Ioannidis, J. P. A. - Baas, J. - Klavans, R. et al.: A Standardized Citation Metrics Author Database Annotated for Scientific Field. PLOS Biology, 17, 8, e3000384, Published: 12 August 2019. DOI: 10.1371/journal.pbio.3000384

O'Regan, B. - Grätzel, M.: A Low-Cost, High-Efficiency Solar Cell Based on Dye-Sensitized Colloidal TiO 2 Films. Nature, Volume 353, Issue 6346, 24 October 1991, 737-740. DOI: $10.1038 / 353737 a 0$

Zhang, D. - Stojanovic, M. - Ren, Y. et al.: A Molecular Photosensitizer Achieves a $V_{o c}$ of 1.24V Enabling Highly Efficient and Stable Dye-Sensitized Solar Cells with Copper(II/I)-Based Electrolyte. Nature Communications, 12, 1777 (2021) Published: 19 March 2021. DOI: 10.1038/s41467-021-21945-3

\section{KÉSZZ̈LŐDÉS NAGY UTAZÁSRA}

A hosszú ürutazások - például Mars-expedició - emberi szervezetre gyakorolt hatását hivatott az a kutatás felderíteni, amelyben a kísérleti alanyok közel 2 hónapot töltöttek egy fejrészével 6 fokkal lefelé megdöntött ágyban. Ez a súlytalanság állapotának földi körülmények között általánosan alkalmazott szimulációja.

A 24 önkéntes (23 és 50 év közötti férfiak és nők) 60 napig voltak szigorúan ágyhoz kötve. Rendszeres időközönként speciálisan asztronauták számára kidolgozott kognitív teszteket végeztettek velük, amelyekkel a térbeli orientációt, a memóriát, a kockázatvállalást és az érzelmek felismerésének képességét lehet értékelni.

A vizsgálatok főképp arra irányultak, hogy a súlytalanság állapotában töltött hosszú idő milyen hatással lehet a kognitív képességekre. A kutatók arra is kíván- 
csiak voltak, hogy napi 30 perc mesterséges gravitáció segíthet-e a súlytalanság okozta esetleges negatív hatások kompenzálásában. Ürutazás közben mesterséges gravitációt az ürhajós forgatásával lehet elóállítani, ezért a kísérleti alanyokat mindennap fél fordulat perc sebességgel egy centrifugában forgatták, úgy, hogy a fejük a forgás tengelyébe esett.

Az eredmények azt mutatják, hogy a kognitív képességek folyamatosan romlottak, és ezen a mesterséges gravitációs kezelés sem segített.

Basner, M. - Dinges, D. F. - Howard, K. et al.: Continuous and Intermittent Artificial Gravity as a Countermeasure to the Cognitive Effects of 60 Days of Head-Down Tilt Bed Rest. Frontiers in Physiology, 17 March 2021. DOI: 10.3389/fphys.2021.643854

\section{EGY LÉPÉSSEL KÖZELEBB A TERMINÁTOROKHOZ}

A Kieli Egyetem és a Heilderbergi Egyetem kutatói olyan eljárást dolgoztak ki, amellyel kiváló elektromos vezetőképességü hidrogélek állíthatók elő. A hidrogélek hidrofil tulajdonságú polimerek, egyre bővülő gyakorlati felhasználásuk közül talán a lágy kontaktlencsék a legismertebbek.

Mechanikailag nagyban hasonlítanak az élő szövetekhez, biokompatibilisek, vezető tulajdonságuk révén pedig alkalmasak lehetnek elektromos jelek továbbítására is. A vezetőképességnek azonban általában ára van: vezető töltőanyag hozzáadása általában a mechanikai tulajdonságok romlásával jár. A most publikált eljárásban rendkívül kis mennyiségü ( 0,16 térfogatszázalék) adalék alkalmazásával értek el kiváló vezetőképességet $(0,34 \mathrm{~S} / \mathrm{m})$. Az így elóállított anyagoknak a bioelektronika és biohibrid robotika területén lehet alkalmazási lehetősége.

Arndt, C. - Hauck, M. - Wacker, I. et al.: Microengineered Hollow Graphene Tube Systems Generate Conductive Hydrogels with Extremely Low Filler Concentration. Nano Letters 2021, Publication Date: March 16, 2021. DOI: 10.1021/acs.nanolett.0c04375 